\title{
The implementation of Customer Relationship Management (CRM) on textile supply chain using k-means clustering in data mining
}

\author{
Anik Dwiastuti ${ }^{1,}{ }^{*}$, Aisyah Larasati ${ }^{1}$ and Endang Prahastuti ${ }^{2}$ \\ ${ }^{1}$ Industrial Engineering Department, State University of Malang, 65145 Malang, Indonesia \\ ${ }^{2}$ Industrial Technology Department, State University of Malang, 65145 Malang, Indonesia
}

\begin{abstract}
Supply chain in textile industry requires an involvement of several other related industry therefore it divide into several sub-sector industry. The market dynamic and complexity of supply chain network are causing problem. This study aims to classify the market base on consumers behaviour through their preferences in textile product in East Java. Analysis of data using data mining approach. Algorithm K-means type clustering is use as clustering methods by integrating with Customer Relationship Management (CRM) concept. The simulation result of data set using five cluster depends on their variability value are Lumajang, Malang, Madura, Tulungagung, and Ponorogo. The clusters formed have the highest importance predictor in "way of purchase" and the lowest in "purchase flexibility". The result in this study is generally indicate that consumers of textile products in East Java prioritize values in customer value compared to product quality.
\end{abstract}

\section{Introduction}

Textile industry is devided into three main sub-sector which are upstream industrial group, intermediate stream and downstream. Most of textile industries in East Java are categorized in downstream industrial group and its supply-chain activity is very dependant to the upstream sector and other supporting industry. Industrial group within downstream subsector are directly connected to end consumer therefore having closer access for consumer information. All inter-connected information with consumer variable in interest change, interest shifting, and purchasing ability, also the demand on product value which is crucial factor to understand. All of the said information are needed by the corporation, especially in implementing their bussiness strategy.

Good understanding on market and consumer behaviour will make the corporation to have a better competitive and more stable sustainability of the bussiness. Sustainable supply chain management is define as the management of the material, information and capital flows and cooperation between companies along the supply chain, while taking into goals from all three dimensions of sustainable development that derive from customer and stakeholder requirement. Bussiness stability in other downstream sub-sector eventualy will

\footnotetext{
* Corresponding author: anik.dwiastuti.ft@um.ac.id
} 
affect the bussiness sustainability on other sub-sector, therefore end-consumer behaviour is a very important source of information in supply chain activity within industrial sector.

Textile industry downstream sub-sector in East Java consist of small and medium industrial scale that most of them have technological limitation on independent market information. While the character demand on textile industrial market is very dynamic. This could trigger the bullwhip effect that caused by the emergence of informational disparity within industrial group in other industrial sub sector. Therefore, this study aim to learn consumer behaviour in their preference towards textile products in East Java using Customer Relationship Management (CRM) concept. Furthermore, preference data is processed using data mining analysis through K-means algorithm to acquire data groups that have high similarity. The model that build could also be source of information on decission making process to support textile industry chain supply activity.

\section{Literature review}

Supply chain management is known as a method to control internal corporation operational activity and corporate interactions with other party mutualy beneficial within business network. A supply chain is the set of value-adding activities that connects a firm's suppliers to the firm's customers. The basic unit of a supply chain activity is receive input from supplier, add value and deliver to customer [1]. Sustainable supply chain management (SSCM) is management of material, information and capital flows as well as cooperation among companies along the supply chain while taking goals from all three dimensions of sustainable development, in example of economic, environmental and social, into account which are derived from customer and stakeholder requirements [8].

Customer relationship management (CRM) is a combination of people, processes and technology that seeks to understand a company's customers. It is an integrated approach to managing relationships by focusing on customer retention and relationship development. CRM is an active, participatory and interactive relationship between business and customer. The objective is to achieve a comprehensive view of customer and be able to consistenly anticipate and react to their needs with targeted and effective activities at every customer touchpoint. Managing a successful CRM implementation requires an integrated and balanced approach to technology, process, and people. Thus, CRM is a more complex and sophisticated application that mines customer data that has been pulled from all customer touch points, creating a single and comprehensive view of a customer while uncovering profiles of key customers and predicting their purchasing patterns.

Data mining is the process of iterative and interactive to discover a pattern or a valid new models, usable and understandable in a very large database. Data mining contains the patterns search or trends in the large database to assist decision making in the future. There is a natural fit between data mining and CRM in that data mining technique, when applied appropriately to the right data can be powerfull tools for formulating and implementing a sound CRM strategy [9]. CRM methods are often used to describe a set of market information that will eventually be made into a database. But now the trend is changing and CRM applications are supported by the data from data warehouses [3]. The method and application of data mining can be used as decission making on CRM toward customer value and customer experience field.

$\mathrm{K}$-means is a type of unsupervised classification method which it partitions data items into one or more cluster. K-Means tries to model a dataset into clusters so that data items in a cluster have similar characteristic and have different characteristics from the other clusters. K-means clustering is a method of data mining process that intend to classify data into some groups which it has similar characteristic within group and differ characteristic with other group. The result of the study using two-stage clustering method can provide a 
company with further understanding of customer for making segmented marketing strategy in Taiwan [4].

\section{Research Methodology}

This research is a case study on textile industry that conducted in five cities which represented of East Java region that is Pamekasan, Malang, Lumajang, Ponorogo and Tulungagung. The data was obtain by means of observation and survey on customers and consumers in that region. Data mining approach is use to build model and analyze. Data mining methodology has a tremendous contribution for researcher to extract the hidden knowledge and informations which have been inherited in the data use by researcher [2]. The procedure performed in this study was begins by examining business processes that take place in the field, so that the retrieved parameter measurement based on the concept of CRM and data collection as a data warehouse. Further build the model through several phase. The first phase is perform aggregation by combining each of data into a bunch of data set. At this stage pre-processing data set are cerried out which aims to analyze the needs of data and reduce uneligible data. The second phase is split data set into three data set that are training, validating dan testing by 20,30 and 50 data set portion. The third stage is building models using algorithms K-means cluster type and further analysis of the results.

The method of clustering with the K-means algorithm using 5 cluster formed and amount of input are 10 fields. Each cluster performance shows variation of the similaritas data. In terms of the diversity of data, the cluster containing low levels of variation data and with other cluster showed a high level of variation. The higher performance of the cluster size, the lower the variability of the data within the group, and the lower the performance of cluster size then the higher the variability within the group. 


\section{Results and Discussion}

The performance of clustering using algorthm K-means shows on table 1.

Table 1. Cluster Build and Size

\begin{tabular}{|c|c|c|c|c|c|c|}
\hline & \multicolumn{5}{|c|}{ Cluster Build } \\
\hline & & $\begin{array}{l}\text { Lumajang } \\
\text { (1) }\end{array}$ & Malang (2) & Madura (3) & $\begin{array}{l}\text { Tulungagung } \\
\text { (4) }\end{array}$ & $\begin{array}{l}\text { Ponorogo } \\
\text { (5) }\end{array}$ \\
\hline Importance & Field & 27,4 & 21,4 & 20 & 15,5 & 15,5 \\
\hline 1,00 & $\begin{array}{l}\text { Way of } \\
\text { purchase }\end{array}$ & $\begin{array}{l}\text { Buy on } \\
\text { marketplace } \\
\qquad(86,9)\end{array}$ & $\begin{array}{l}\text { Buy on } \\
\text { marketplace } \\
(55,5)\end{array}$ & $\begin{array}{l}\text { Buy on } \\
\text { galery } \\
\\
(88,2)\end{array}$ & $\begin{array}{l}\text { Order on } \\
\text { artisan } \\
\qquad(84,6)\end{array}$ & $\begin{array}{l}\text { Order on } \\
\text { artisan } \\
\qquad(92,31)\end{array}$ \\
\hline 0,73 & Price & $\begin{array}{r}<\mathrm{Rp} 100.000 \\
(100) \\
\end{array}$ & $\begin{array}{r}<\text { Rp. } 100.000 \\
(100) \\
\end{array}$ & $\begin{array}{l}\text { Rp.500.000- } \\
1.000 .000 \\
\\
(41,18) \\
\end{array}$ & $\begin{array}{l}\text { Rp.100.000- } \\
200.000 \\
\quad(46,15) \\
\end{array}$ & $\begin{array}{l}\text { Rp.100.000- } \\
200.000 \\
(61,54) \\
\end{array}$ \\
\hline 0,69 & $\begin{array}{l}\text { Quality } \\
\text { Perception }\end{array}$ & $\begin{array}{ll}\text { Fair } & \\
& (65,2) \\
\end{array}$ & $\begin{array}{l}\text { Good } \\
\quad(77,78) \\
\end{array}$ & $\begin{array}{r}\text { Very Good } \\
(64,7) \\
\end{array}$ & $\begin{array}{l}\text { Good } \\
\quad(38,46)\end{array}$ & $\begin{array}{l}\text { Fair } \\
\quad(61,54) \\
\end{array}$ \\
\hline 0,66 & $\begin{array}{l}\text { Accses of } \\
\text { Product } \\
\text { Information }\end{array}$ & $\begin{array}{l}\text { Market } \\
\text { place }\end{array}$ & $\begin{array}{l}\text { Market } \\
\text { place }\end{array}$ & $\begin{array}{l}\text { Dissplay on } \\
\text { store }\end{array}$ & $\begin{array}{l}\text { Promotion } \\
\text { word of } \\
\text { mouth } \\
\qquad(61,54)\end{array}$ & $\begin{array}{l}\text { Promotion } \\
\text { word of } \\
\text { mouth } \\
\qquad \quad(84,61) \\
\end{array}$ \\
\hline 0,42 & $\begin{array}{l}\text { Sum of } \\
\text { purchase }\end{array}$ & $\begin{array}{l}6 \text { times } \\
(60,87)\end{array}$ & $\begin{array}{l}6 \text { times } \\
(77,77)\end{array}$ & $\begin{array}{l}12 \text { times } \\
(64,77)\end{array}$ & $\begin{array}{l}12 \text { times } \\
\quad(84,61) \\
\end{array}$ & $\begin{array}{r}6 \text { times } \\
(92,3) \\
\end{array}$ \\
\hline 0,36 & Dyestuff & $\begin{array}{l}\text { Nature } \\
\qquad(43,5)\end{array}$ & $\begin{array}{l}\text { Nature } \\
\\
\end{array}$ & $\begin{array}{l}\text { Nature } \\
\qquad(52,9)\end{array}$ & $\begin{array}{l}\text { Nature } \\
\qquad(52,9)\end{array}$ & $\begin{array}{l}\text { Rhemasol } \\
\qquad(38,46)\end{array}$ \\
\hline 0,28 & Information & $\begin{array}{l}\text { Type of } \\
\text { product } \\
\qquad(56,5)\end{array}$ & $\begin{array}{l}\text { Variance } \\
\text { product } \\
\qquad(38,8)\end{array}$ & $\begin{array}{l}\text { Variance } \\
\text { product } \\
\qquad(38,8)\end{array}$ & $\begin{array}{l}\text { Reactive } \\
\text { base } \\
\qquad(69,23)\end{array}$ & $\begin{array}{l}\text { Product } \\
\text { custom } \\
\qquad(61,54)\end{array}$ \\
\hline 0,23 & $\begin{array}{l}\text { Time } \\
\text { Experience }\end{array}$ & $\begin{array}{c}1-3 \text { years } \\
(69,6)\end{array}$ & $\begin{array}{r}3-6 \text { years } \\
(66,6)\end{array}$ & $\begin{array}{c}1-3 \text { years } \\
(35,29)\end{array}$ & $\begin{array}{l}3-6 \text { years } \\
(61,54)\end{array}$ & $\begin{array}{c}3-6 \text { years } \\
(61,54)\end{array}$ \\
\hline 0,22 & Fabric & $\begin{array}{ll}\text { Silk } & \\
& \\
& (47,8)\end{array}$ & Silk & $\begin{array}{l}\text { Silk } \\
\\
\end{array}$ & $\begin{array}{ll}\text { Silk } & \\
& (92,53)\end{array}$ & $\begin{array}{l}\text { Voile } \\
\qquad(84,61)\end{array}$ \\
\hline 0,06 & $\begin{array}{l}\text { Flexibility } \\
\text { to purchase }\end{array}$ & $\begin{array}{l}\text { Variation } \\
\text { quality } \\
\qquad(34,7)\end{array}$ & $\begin{array}{l}\text { Easy accses } \\
\qquad(33,3) \\
\end{array}$ & $\begin{array}{l}\text { Price vary } \\
\qquad(29,54)\end{array}$ & $\begin{array}{l}\text { Price vary } \\
\qquad(53,84)\end{array}$ & $\begin{array}{l}\text { Price vary } \\
\qquad(46,15)\end{array}$ \\
\hline
\end{tabular}

*the value is shown in percentage

The table 1 ilustrates the size of each cluster as result of K-means model by set five cluster. The first cluster with the highest size is 27.4 indicates that the level of variability in the lowest group that is displayed by Lumajang city. The second clusters with size 21.4 is Malang city, third cluster with size 20 is Madura, and cluster 4 and 5 have the same size are Tulungagung and Ponorogo with size are $15,5 \%$. Way of purchase is a field that has a perfect score (1.00) which is considered the most important by consumers, based on the degree of similarity is high on how to obtain the products do consumers through the purchase. While the other field of price, quality perception, accses of product information, sum of purchase, dyestuff, information, time experience, fabric and flexibility to purchase in order to have the value of importance that are getting smaller.

The result shows in table 1 which was formed based on the CRM concept may explain the position of the three preferences field by consumers i.e. customer value, product quality and experience are the measurement that represent the needs of the consumer of East Java. Next briefly be described in diagram predictor importance as shown in table 2 below. 
Table 2. Pedictor Importance Each Field

\begin{tabular}{|cc|}
\hline Nodes of Field & Importance \\
\hline FLEXIBILITY TO PURCHASE & 0.0629 \\
\hline FABRIC TYPE & 0.2226 \\
\hline TIME EXPERIENCE & 0.2307 \\
\hline INFORMATION & 0.2783 \\
\hline TYPE OF DYESTUFF & 0.3561 \\
\hline SUM OF PURCHASE PER YEAR & 0.4188 \\
ACCESS OF PRODUCT INFORMATION & 0.6554 \\
QUALITY PERSEPTION & 0.6893 \\
\hline PRICE & 0.7332 \\
\hline WAY OF PURCHASE & 1 \\
\hline
\end{tabular}

The overview of consumer preference specifically for raw materials of textile products that represent measurements of product quality shows in table 3 and 4 below. The preferences on the type of fabric is different in each city, which is indicated by the value of chisquare 348 with $\mathrm{df}=20$ and $\alpha=0,05$ on $\chi^{2}=31,41$ which shows there are significant differences in each area. The preferences on the type of dyestuff is also different in each citiy which is indicated by the value chisquare 347 with $\mathrm{df}=16$ and $\alpha=0,05$ on $\chi^{2}=26,30$.

Table 3. Fabric Type Cluster by Area

\begin{tabular}{llllll}
\hline AREA & Indigosol & Naphtol base & Nature dyestuff & Reactive base & Rhemasol \\
\hline Lumajanag & 13 & 9 & 11 & 98 & 29 \\
Madura & 9 & 27 & 89 & 32 & 3 \\
Malang & 41 & 40 & 52 & 29 & 8 \\
Ponorogo & 39 & 33 & 45 & 3 & 0 \\
Tulungagung & 43 & 38 & 51 & 8 & 0 \\
\hline
\end{tabular}

Table 4. Dyestuff Cluster by Area

\begin{tabular}{llllll}
\hline AREA & Finished Cotton & Poplin & Raw cotton & Rayon & Silk \\
\hline Lumajang & 0 & 0 & 0 & 0 & 74 \\
Madura & 16 & 9 & 0 & 2 & 123 \\
Malang & 6 & 2 & 1 & 36 & 103 \\
Ponorogo & 12 & 16 & 4 & 11 & 35 \\
Tulungagung & 20 & 13 & 3 & 7 & 59 \\
\hline
\end{tabular}

Table 4 and 5 describes the existence of differences of fondness and purchasing power of textile product in each region. The character of consumer textile products are divided into three groups that are self consumers, social consumers, dan sacrifice consumers that each purchase decision behavior and motivations vary [5]. These data performance can be used as a primary in the planning of the supply of raw materials and other supply chain activities. Customer involvement is needed in the form of cooperative relationship between sub sectors of the cluster as a strategy for competing in the sustainability of development [7]. 


\section{Conclusions}

Based on the results, this study concludes that consumer preferences using CRM concept shows the implications of the model of clustering that is based on the measuring consumer preferences then the business strategy and supply chain activities in the textile industry in East Java can be managed. Build a strong relationship between customer in order to grow the consumer value, manage inventory and procurement of materials production, as well as restrain on the quality of the textile product.

The authors acknowledge to the Institute of Research and community Services (LP2M) Universitas Negeri Malang for supporting this study as a financial source on managing the university research fund (PNBP) year 2018.

\section{References}

1. Harrison. Terry.P, Lee. Hau.L, Neale. John.J, NY. Springer, (2005). I.J.Chen, Popovich. K, , BPM Journal, 9 672-688 (2003)

2. Hosseini, S.M.S, Maleki. A, Gholamian. M.R, Exp.Sys. with Application, 37, 52595264, (2010)

3. Khan. A, Ihsan.N, Mirza.E, Sarwa, Proced.Tech. 1 239-249 (2012)

4. Li. Dher-Chiang, Dai. When-Li, Tseng.Wan-Ting, Exp.Sys.with Application, 38 7186-7191 (2011)

5. McNeill Lisa, Moore Rebecca, Int. Journal of Consumer Studies 39, 212-222, (2015)

6. $\quad$ Ozgener. S, Iraz. R, J.Tourman 27 1356-1363 (2006)

7. Saracha, Liliya, 191 250-254 (2015)

8. $\quad$ Seuring. S, Muller. M, J.Clean.Prod 16 1699-1710, (2008)

9. R. S Winer, 43 89-105, (2001) 